\title{
Gastroptosis: A cause of postprandial abdominal bloating
}

\author{
STEPHEN N SULLIVAN, MD, FRCPC, FRCPC(LOND)
}

\begin{abstract}
SN SULLIVAN. Gastroptosis: A cause of postprandial abdominal bloating. Can J Gastroenterol 1991;5(4):126-128. Ptosis of the food-and fluid-filled stomach is described as an 'organic' explanation for postprandial abdominal bloating in six patients. Demographic data, precipitating foods, radiography and gastric emptying times are presented. Therapy with support hose, a girdle, domperidone and cisapride were variously perceived to be helpful.
\end{abstract}

\section{Key Words: Abdominal bloating, Gastroptosis}

\section{Gastroptose: Une cause du ballonnement post-prandial}

RESUME: La ptose de l'estomac rempli d'aliments ou de liquide est décrite à titre d'explication «organique» du ballonnement abdominal post-prandial chez six patients. Données démographiques, aliments déterminants, radiographie et temps d'évacuation gastrique sont présentés. L'utilité des traitements prescrivant les collants de contention, les gaines, le dompéridone et le cisapride est perçue de façon diverse.

\begin{abstract}
A BDOMINAL BLOATING AFTER EATing is a common but nonspecific symptom. If an organic explanation cannot be found, bloating is often considered 'functional'. Six patients are described in whom gastroptosis was the 'organic' explanation for postprandial abdominal bloating.
\end{abstract}

\section{PATIENTS AND METHODS}

All patients were referred for gastrointestinal consultation (Table 1). In every case the major complaint was uncomfortable, visible, postprandial bloating. Clues to an organic explanation were sought in a detailed history and physical examination, which included a search for psychiatric problems, aerophagia, malabsorption, connective tissue disease and autonomic neuropathy, as well as structural disease of the gastrointestinal tract. A detailed dietary history was also taken. Past investigations were reviewed. All patients had had normal upper gastrointestinal series, small
Gastrointestinal Unit, Victoria Hospital, London, Ontario

Correspondence and reprints: Dr SN Sulliwan, King Fahad Hospital, Department of

Medicine, PO Box 22490, Riyadh 11426, Saudi Arabia

Received for publication June 6, 1991. Accepted June 28, 1991 bowel follow-through and barium enema. Lactose tolerance tests $(50 \mathrm{~g}, 2 \mathrm{~h})$ were normal and did not cause bloating in the three patients who drank milk. A work-up for malabsorption was negative in one patient (case 2) who had lost weight.

All patients were asked to bring a lunch which they were sure would cause bloating. Prior to the meal they were examined for succussion splash and gaseous abdominal distension. The contours of the abdomen in the supine and upright positions were recorded. The patients then ate their lunches along with $60 \mathrm{~mL}$ of barium suspension (EZ EM Company, New York). When the bloating hegan they were re-examined and sent for an upright $\mathrm{x}$-ray of the abdomen.

After gastroptosis was identified as a possible cause of the patient's bloating, gastric outlet obstruction was excluded on another day by endoscopy, and gastroparesis was excluded by a radioisotope gastric emptying study using technetium-99m sulphur colloid and an egg salad sandwich.

\section{DISCUSSION}

Visible distension of the abdomen after eating (bloating) may be due to aerophagia, gluttony, gastric outlet or intestinal obstruction, malabsorption, or hypomotility of the stomach or intestine. If an organic cause cannot be 


\section{TABLE 1 \\ Data of six patients experiencing postprandial abdominal bloating}

\begin{tabular}{|c|c|c|c|c|c|c|c|}
\hline Case & Sex & Age & $\begin{array}{l}\text { Duration of } \\
\text { symptoms }\end{array}$ & $\begin{array}{c}\text { Gastric } \\
\text { emplying } t^{1} / 2\end{array}$ & Test meal & $\begin{array}{l}\text { Helpful } \\
\text { treatment }\end{array}$ & Comment \\
\hline 1 & $\mathrm{~F}$ & 39 & 6 years & $65 \mathrm{mins}$ & Egg salad sandwich & $\begin{array}{l}\text { Support } \\
\text { pantyhose }\end{array}$ & $\begin{array}{l}\text { Bloating first developed after } \\
\text { difficult breech delivery of } \\
\text { child }\end{array}$ \\
\hline 2 & F & 35 & 5.5 years & 52 mins & $\begin{array}{l}\text { Chocolate milk, } 2 \text { cookies, } \\
\text { and one-half peanut butter } \\
\text { sandwich }\end{array}$ & Trying girdle & $\begin{array}{l}\text { Discomfort from bloating led to } \\
\text { weight loss of } 4 \mathrm{~kg}\end{array}$ \\
\hline 3 & F & 27 & 6 months & 45 mins & $\begin{array}{l}\text { Ham and lettuce sandwich, } \\
\text { diet Coke }\end{array}$ & $\begin{array}{l}\text { Domperidone } \\
10 \mathrm{mg} \mathrm{ac}\end{array}$ & \\
\hline 4 & F & 41 & 6 years & $32 \mathrm{mins}$ & $\begin{array}{l}\text { Tuna sandwich, apple, } \\
\text { chocolate milk }\end{array}$ & $\begin{array}{l}\text { Domperidone } \\
10 \mathrm{mg} \mathrm{ac}\end{array}$ & $\begin{array}{l}\text { Also has irritable bowel } \\
\text { syndrome }\end{array}$ \\
\hline 5 & F & 33 & 8 months & 77 mins* & $\begin{array}{l}\text { Pickled pig's feet, Coke, potato } \\
\text { chips }\end{array}$ & $\begin{array}{l}\text { Cisapride } 10 \\
\mathrm{mg} \mathrm{ac}\end{array}$ & $\begin{array}{l}\text { Barium enema shows ptosis of } \\
\text { colon. Very weak abdominal } \\
\text { muscles. }\end{array}$ \\
\hline 6 & F & 23 & 2 years & 90 mins $^{*}$ & Hamburger and french fries & $\begin{array}{l}\text { Domperidone } \\
10 \mathrm{mg} \mathrm{ac}\end{array}$ & Mastalgia from domperidone \\
\hline
\end{tabular}

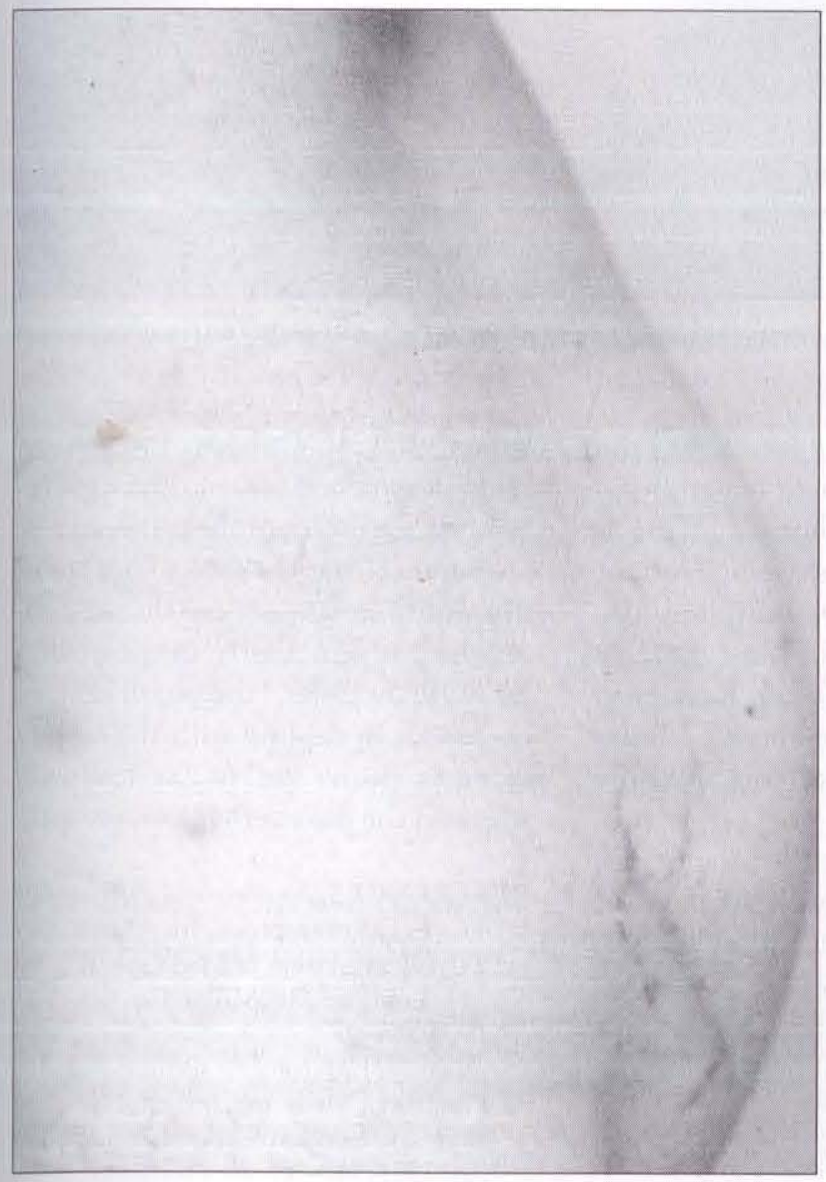

Figure 1) Abdominal bloating in case 1 after test meal

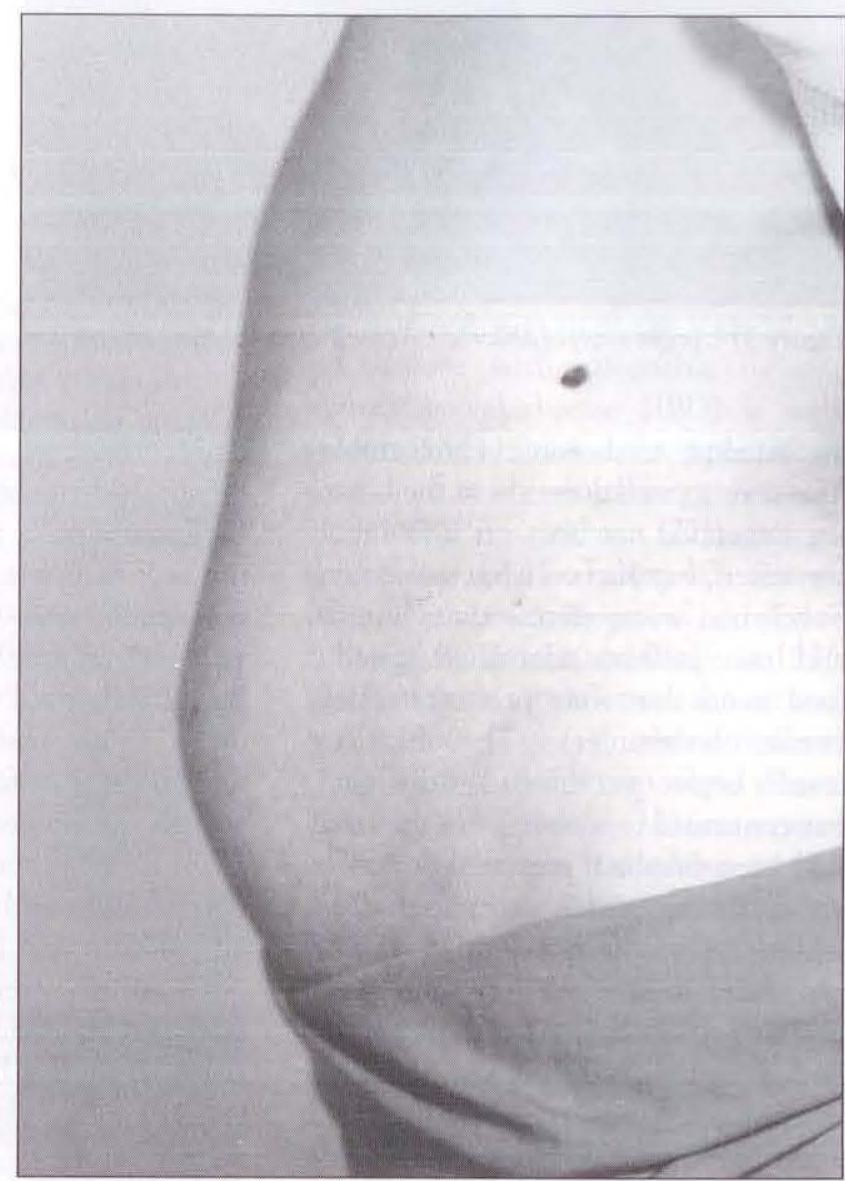

Figure 2) Abdominal bloating in case 6 after test meal found, then bloating is often considered 'functional' and part of the spectrum of the irritable bowel syndrome. A century ago this was known as Glénard's disease, and was later renamed enteroptosis or visceroptosis (1). Osler felt the problem was 'neurasthenic' (2), a term which the present author interprets to be equivalent to 'functional'. However, ptosis of the fluid-and food-filled stomach should be considered as an organic explanation for this symptom. It is easy to recognize. The bloating is lower abdominal and may be slightly asymmetrical, being more prominent on the left. Not only do the patients feel bloated, they look bloated (Figures 1,2). Several likened their appearance to being pregnant. They frequently loosened or changed their clothing in 


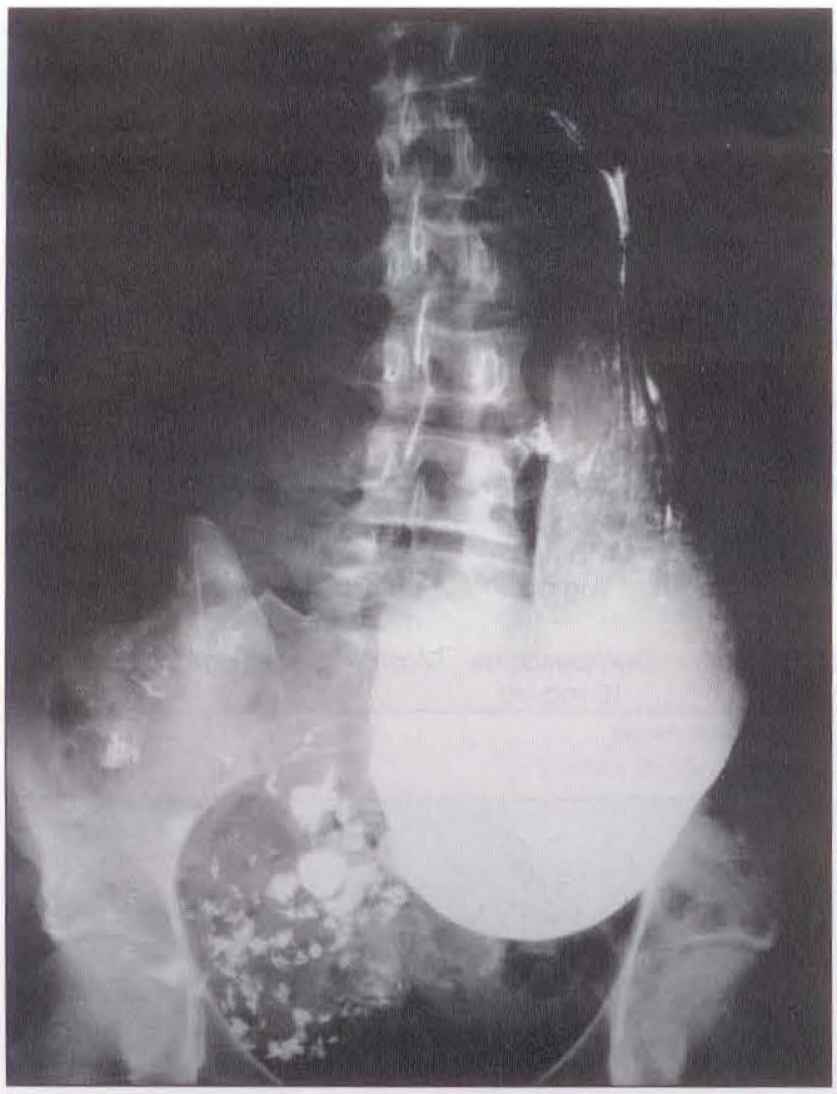

Figure 3) Upright x-ray of abdomen in case 1 after test meal and barium

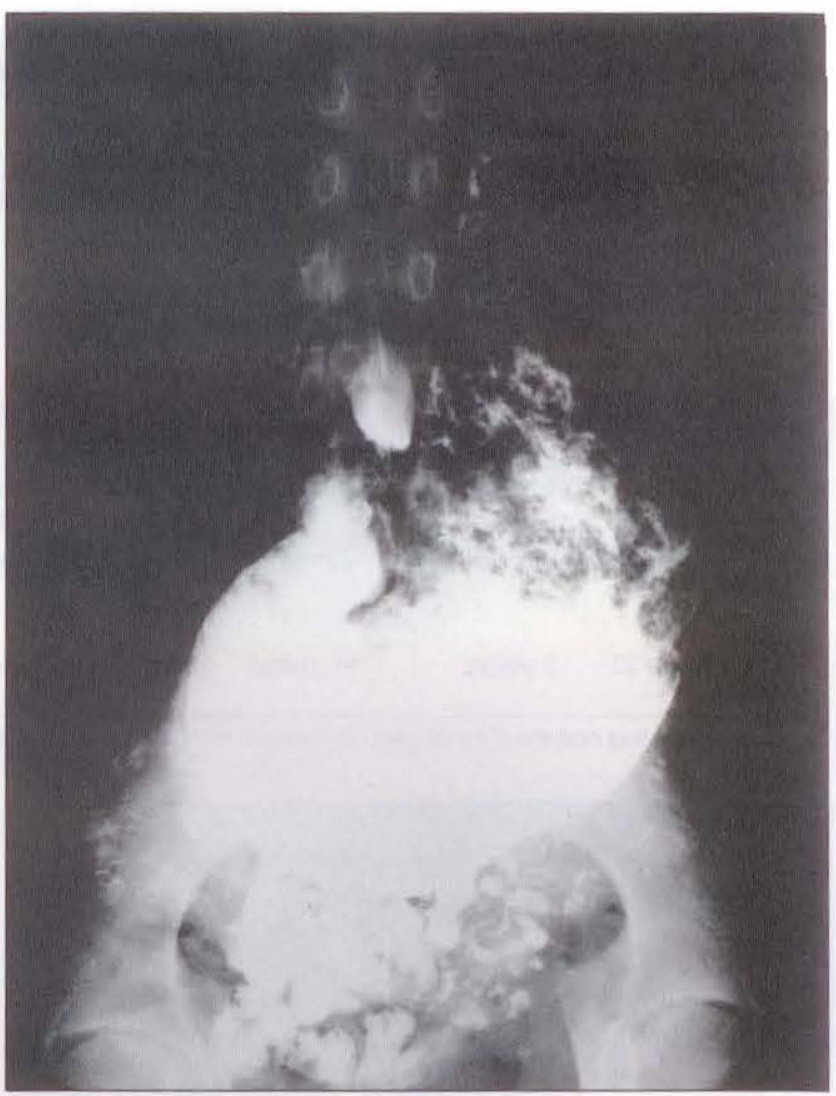

Figure 4) Upright $x$-ray of abdomen in case 6 after test meal and barium. an attempt to become comfortable. The severity and duration of the bloating depended not only on how much was eaten, but also on what was eaten. Solids had worse effects than liquids, and two patients identified specific food items that were prime offenders (steak, hamburger). The bloating usually began near the end of the meal, but continued to worsen after the meal had been finished, presumably due to accumulating gastric secretions. The whole episode lasted 1 to $3 \mathrm{~h}$ and gradually resolved before the next meal. A small amount of oral barium and an upright $\mathrm{x}$-ray of the abdomen when the patient is visibly distended will confirm the diagnosis. The fluidand food-filled stomach outlined by the barium can be seen lying in front of the lumbosacral promontory (Figures 3,4).
This corresponds to the location of the bloating when the patient is standing.

Treatment is problematic. This is not a disease, but an anatomic variant of normal, beautifully illustrated 100 years ago by Ewald (3). Most patients had already tried smaller and 'easier to digest' meals. Gastric emptying studies were normal in four patients and only slightly prolonged in the other two. Empiric treatment with prokinetics, domperidone and cisapride, was tried in all patients, and four felt they helped. Abdominal strengthening exercises were recommended to one patient (case 5), but she did not persist with the exercises. Two patients (cases 1 and 2) were relieved by wearing a well constructed girdle or support pantyhose - a modification of Osler's highly recommended "well-adapted abdominal bandage" (2). Perhaps the greatest relief of symptoms was in the explanation to the patient of the cause, and the reassurance that they were "not crazy", nor was there any serious disease causing the problem. Lastly, in the words of Sir William Osler, "the physician must be careful in dealing with the subjects of enteroptosis not to lay too much stress on the disorder" (2).

\section{REFERENCES}

1. Treves F. Enteroptosis. In: Allbutt, TC, ed. A System of Medicine, vol 111. London: MacMillan Co, 1905:587-97.

2. Osler W. Enteroptosis. Principles and Practise of Medicine, 8 th edn. New York and London: D Appleton and Co, 1918:548-50.

3. Ewald CA. Diseases of the Stomach. New York: D Appleton and Co, 1892:110-2. 


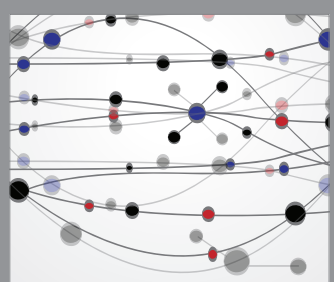

The Scientific World Journal
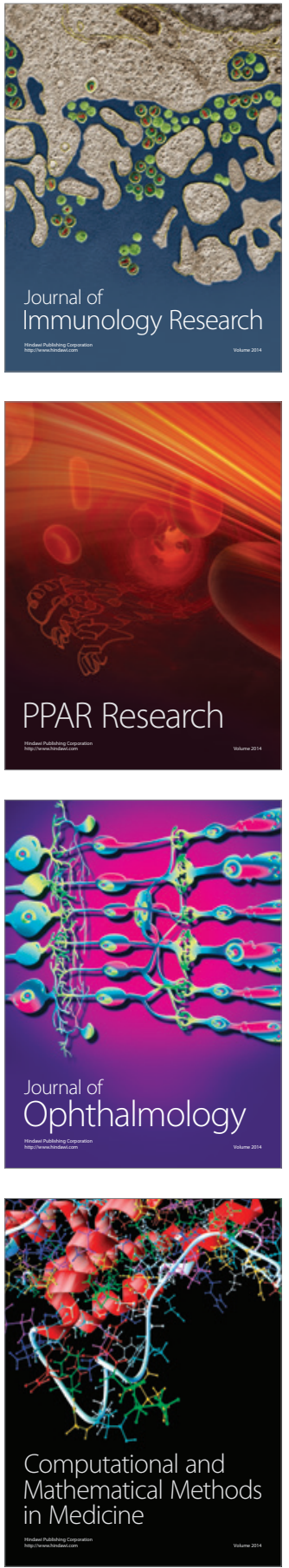

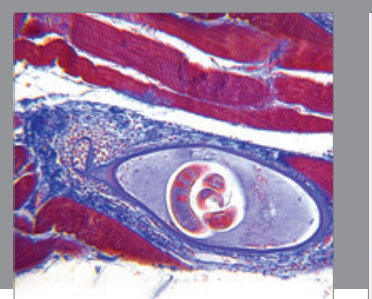

Gastroenterology Research and Practice

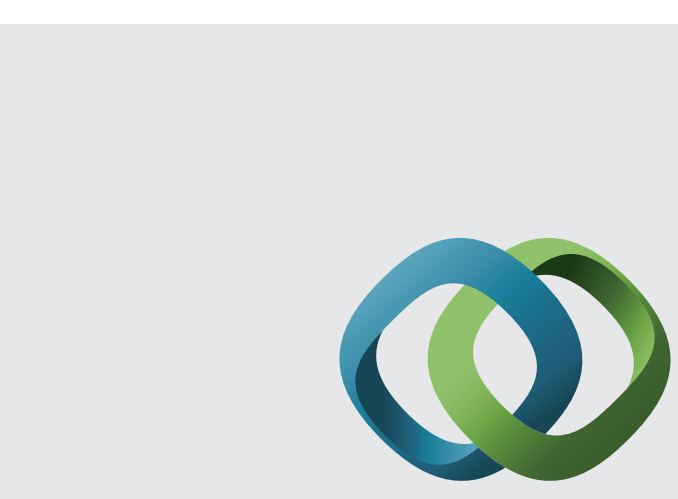

\section{Hindawi}

Submit your manuscripts at

http://www.hindawi.com
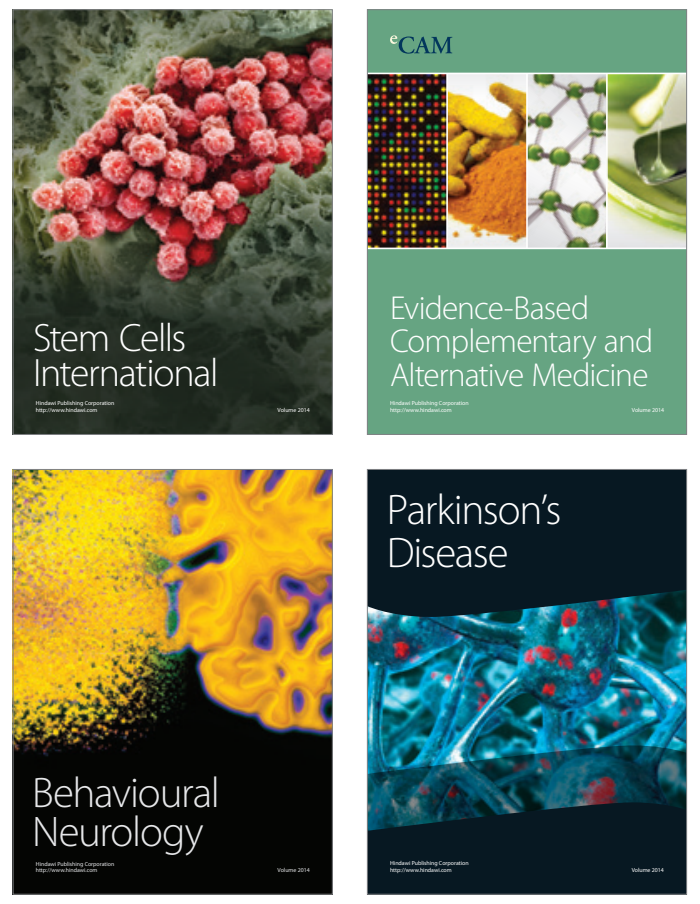
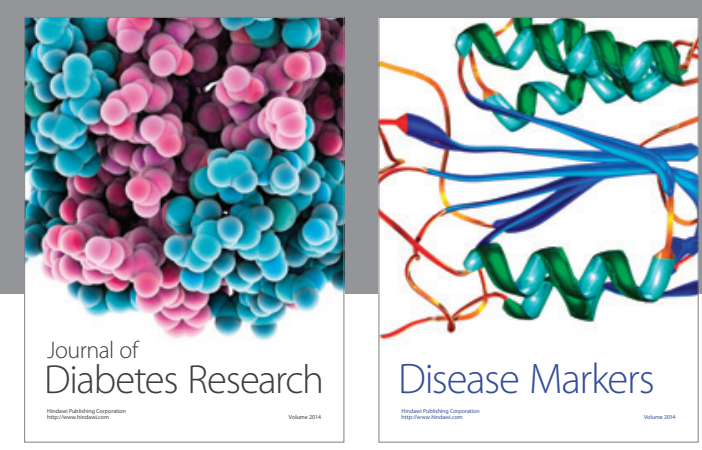

Disease Markers
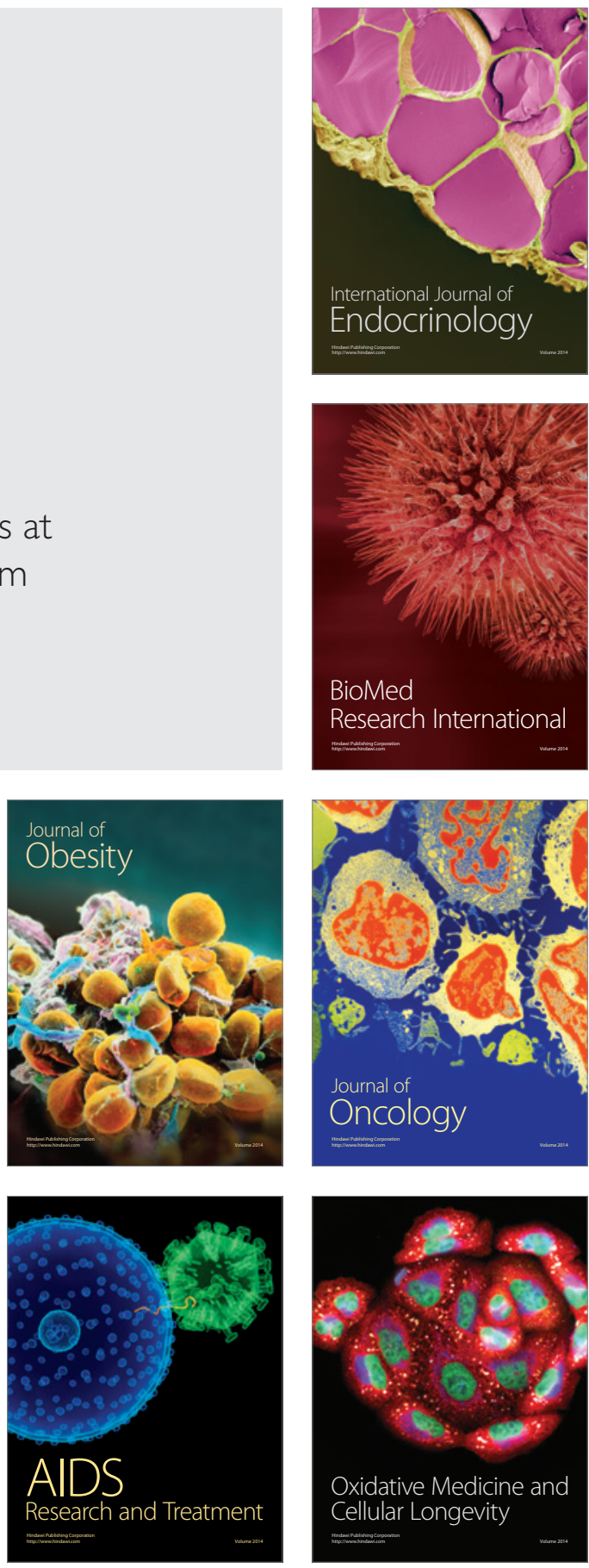